\title{
KESULTANAN SIAK \\ Antara Johor dan VOC
}

\section{Ellya Roza}

UIN Sultan Syarif Kasim Riau

Email: asmal.may@uin-suska.ac.id

\section{Masbukin}

UIN Sultan Syarif Kasim Riau

Email: masbukin@,uin-suska.ac.id

Abstrak:

Tulisan ini mendiskusikan tentang bubungan antara Siak dan Johor dan VOC, Belanda. Siak merupakan pintu gerbang Johor dari arah darat Sumatera, manakala Sungai Siak pula merupakan urat nadi pengangkutan masa itu karena Sungai Siak termasuk sungai yang memiliki kedalaman sebingga memudabkan kapal-kapal besar berlayar menuju Selat Melaka. Hubungan di antara Siak dan VOC sama saja dengan bubungan Johor dengan VOC karena pada masa itu kawasan Siak pula merupakan kawasan Johor. Hal ini bermakna apa yang berlaku ke atas Johor, maka berlaku pula di Siak. Akan tetapi, bagi Belanda, Sungai Siak yang bermula dari Selat Malaka merupakan jalur lalu lintas penting babkan Belanda amat mementingkan Sungai Siak tersebut untuk melancarkan perjalanannya ke daerah.

Kata Kunci: Siak, Voc, Johor

Abstract:

This paper discusses the relationship between Siak and Johor and the VOC, Netherlands. Siak is the gateway to Johor from the land direction of Sumatra, when the Siak River was also the lifeblood of transportation at that time because the Siak. River was a river that had a depth that made it easier for large ships to sail to the Melaka Strait. The relationship between Siak and the VOC was the same as Johor's relationship with the VOC because at that time the Siak area was also Johor area. This means that what applies to Johor is also true in Siak. However, for the Netherlands, the Siak River, which originated from the Malacca Strait, was an important traffic route and the Dutch placed great importance on the Siak River to make its way to the region.

Keywords: Siak, Johor, VOC

\section{PENDAHULUAN}

Masyarakat Melayu yang hidup dan berkembang di negeri Siak merupakan turunan daripada ras rumpun Deutro-Melayu yang mendesak ras Proto-Melayu. Sebagai turunan yang masih wujud di negeri Siak dapat dilihat daripada suku yang lebih tua yaitu suku yang hidup jauh di pedalaman misalnya suku Sakai yang hidup di Mandau, Minas, Duri, dan Sungai Apit. Manakala Suku Akit hidup di Hutan Panjang Rupat, Bengkalis dan Suku Hutan pula hidup di Tanah Putih dan Selat Panjang. ${ }^{1}$ Mereka hidup dengan sangat sederhana sehingga sekarang masih dapat disaksikan keberadaan mereka di beberapa negeri yang disebutkan tadi. Oleh itu, bermakna orang Melayu berabad-abad yang lalu telah mendiami kawasan di pesisir dan daratan Sumatra dengan meyakini kepercayaan nenek

1 Perkara ini banyak dibincangkan oleh Mukhtar Lutfi, et.al., 1977, Sejarah Riau, Pekanbaru: UNRI Press, hlm. 57-61; Husni Tamrin 2003, Sakai, kekuasaan, pembangunan dan marjinalisasi, Pekanbaru: Gagasan Press. Suku bangsa yang hidup di negeri-negeri seperti yang disebutkan di atas termasuk dalam negeri Siak. 


\section{NUSANTARA; Journal for Southeast Asian Islamic Studies}

Vol. 16, No. 1, Juni 2020

moyang secara turun temurun. ${ }^{2}$ Akan tetapi setelah Islam datang, maka orang Melayu ramai meyakini Islam. Islam memegang peranan penting karena Kemaharajaan Melayu lah yang meletakkan konstruksi dan sistem nilai Islam yang mampu menghakis sistem Melayu lama yang dimiliki animisme, dinamisme dan Hinduisme ke dalam sistem nilai Melayu yang dipengaruhi oleh nilai-nilai Islam.

Tidak dinafikan pula bahwa Nusantara sudah mempunyai satu corak kebudayaan yang menyeluruh pada zaman para-sejarah. Dalam hal ini dikatakan bahwa menjelang kedatangan pengaruh Hindu, masyarakat Melayu dikatakan hidup secara berkelompok dan mengusahakan pertanian, tidak lagi berpindah-randah atau berburu. Mereka sudah mempunyai hubungan keluarga, sudah ada kumpulan dan sudah ada kawasan kediaman. Demikian pula masyarakat di negeri Siak yang pada suatu masa dahulu merupakan sebahagian daripada masyarakat Kesultanan Melayu. Hal ini bermakna masyarakat yang ada dan berkembang di negeri Siak adalah masyarakat suku bangsa Melayu karena penyebaran penduduk pula sampai ke negeri Siak sehingga sebahagian besar penduduknya disebut suku bangsa Melayu.

Kehidupan masyarakat Siak bersifat gotongroyong sebagai perwujudan daripada suatu bentuk tolong menolong. Tolong menolong merupakan salah satu bentuk solidaritas khas daripada masyarakat tradisional. Masyarakat tersebut terikat antara satu dengan lainnya berdasarkan hubungan sosial melalui ikatan keluarga, dekatnya letak geografis dan kepercayaan yang diyakini. Manakala masyarakat yang hanya di dasarkan pada ikatan emosional dan solidaritas mekanik, dikenal sebagai masyarakat yang terintegrasi secara struktural. Oleh karena itu dapat dikatakan bahwa masyarakat Siak adalah masyarakat pengembara di mana kawasan pengembaraannya cukup luas. Mereka dapat menyesuaikan diri dengan lingkungan alam tempat tinggal. Pada masanya ada yang menetap di daerah pesisir, di tepian-tepian sungai dan di pedalaman. Kehidupan mereka sesuai dengan kondisi alam

${ }^{2}$ Husni Tamrin, 2007, Etnografi Melayu Tradisi dan Modernisasi, Pekanbaru: Suska Press, hlm.1-2. persekitarannya. Ada yang menangkap ikan dan ada pula yang bercocok tanam atau lainnya.

\section{Antara Siak dan Johor}

Sebelum Kerajaan Siak didirikan oleh Raja Kecil, negeri Siak berada dalam kawasan Kerajaan Johor - Riau. Pada masa itu di Siak dilantik seorang raja yang bertugas sebagai wakil pemerintahan Kerajaan Johor. Manakala Kerajaan Johor telah pula menjalin persahabatan dengan Belanda dalam rangka menghadapi Portugis. Dalam catatan Anrooij (1885) dicatatkan bahwa raja yang diletak di Siak merupakan seorang raja boneka Johor sahaja, artinya raja di Siak tidak memiliki kekuasaan. Kemudian pada masa berikutnya di Siak tidak lagi ada raja akan tetapi ditempatkan seorang syahbandar sebagai pengganti raja yang bertugas memungut cukai barang-barang yang masuk dan keluar melalui sungai Siak. Penempatan syahbandar ini berketerusan hampir satu ratus tahun lamanya yang bermula pada tahun 1662. Selepas itu pihak kerajaan Johor berasa tidak perlu lagi menempatkan syahbandar di Siak kerana penghasilan negeri Siak sudah mulai berkurang sehingga tidak menguntungkan bagi kerajaan Johor. ${ }^{3}$

Oleh karena itu, dapat dikatakan bahwa berakhirnya penempatan syahbandar di Siak berdasarkan pertimbangan ekonomi dan bukan berdasarkan pertimbangan politik maupun pertahanan dan keamanan. Dari segi ekonomi dianggap bahwa kalau di Siak didudukkan seorang raja akan memerlukan pembiayaan yang besar sedangkan perdagangan di Siak dan sepanjang aliran sungai Siak belum begitu menguntungkan. Timah dan emas merupakan komoditi utama dari Petapahan Kampar hanya tersedia puluhan pikul saja tidak seperti yang diharapkan. Akan tetapi dari segi politik, kerajaan Johor berasa yakin bahawa Siak mempunyai kekuatan yang tangguh. Menurut Netscher (1870) ${ }^{4}$ berdasarkan

3 Mengenai kedudukan raja di Siak banyak dibincangkan dalam laporan H.A.Hijmans Anrooij, op.cit., hlm. 262.

4 Netscher adalah seorang Belanda yang lama tinggal di Riau. Ia hidup sezaman dengan Raja Ali Haji. Selama di Riau, ianya bertugas sebagai pejabat di kantor Residen dan bahkan dalam waktu yang cukup lama pernah menjadi Residen Riau. Selain jabatan itu, ia banyak 
pertimbangan itulah maka mulai tahun 1662 di Siak ditempatkan seorang syahbandar yang bertugas memungut cukai bagi barang-barang yang keluar dan masuk sungai Siak. Penempatan syahbandar tersebut bertempat di Sabak Auh dan berlangsung hingga tahun 1722 menjelang Kerajaan Siak didirikan. Dengan penempatan syahbandar tersebut berarti Siak masih tunduk dan taat kepada Johor.

Sungai Siak yang mengaliri negeri Siak dan bermuara di Selat Melaka sangat berperanan dalam aspek transportasi guna sampai ke Johor kerana Sungai Siak merupakan sungai yang dalam sehingga boleh dilewati oleh kapal-kapal niaga yang besar. Mengenai keadaan Sungai Siak tercatat dalam Memorie van Overgave ${ }^{5}$ yang mengatakan bahwa di Sungai Siak tidak ditemukan tumpukan-tumpukan lumpur, pasir atau kerikil yang mengganggu perjalanan kapal. Apalagi air sungai ini tidak berasal dari pegunungan yang menyebabkan terjadinya banjir, akan tetapi airnya berasal dari rawa-rawa dan dataran rendah lainnya di mana airnya diserap oleh tanaman dan mengalir dengan sangat lambat sehingga arus sungai amat menguntungkan perjalanan.

Siak dan Johor tidak dapat dipisahkan dan ternyata Siak dengan Johor merupakan sebuah kesatuan yang saling berkaitan rapat karena kedua-dua wilayah sama-sama memiliki fungsi yang saling menyokong satu dengan lainnya. Siak pada zaman lampau merupakan pintu gerbang masuk Johor dari arah darat pulau Sumatera jika kapal hendak berlayar membawa barang dagangannya melalui Selat Melaka menuju Johor. Demikian pula Sungai Siak merupakan urat nadi

menerjemahkan karya-karya Riau termasuk karya Raja Ali Haji ke dalam Bahasa Belanda. Di samping menerjemahkan buku-buku Riau ke dalam Bahasa Belanda, juga sekaligus menulis tentang situasi dan kondisi Riau pada masanya ia di Riau. Karya Netscher yang berkaitan dengan Siak adalah De Nederlanders in Djobor en Siak 1602 tot 1865 Historische Beschrijving. Buku tersebut dicetak pada tahun 1870 di Batavia. Catatan Netsher yang lain Beschrijuing Van Een Gedeelte DerResidentie Riouw, Batavia : Lange, Diterbitkan oleh TBG no. 2 tahun 1854.

5 Mengenai hal ehwal sungai Siak banyak dibincangkan oleh W.J. Leyd, 20 Mei 1929 yang tercatat dalam Memorie Van Overgave der Ondeafdeeling Siak, Rioun en Onderhoorigheden, Catatan tersebut menjadi simpanan Arkib Nasional Republik Indonesia (ANRI), Reel no. 18 MvO. Ie. transportasi masa itu karena Sungai Siak termasuk sungai yang terdalam di wilayah Nusantara sehingga memudahkan kapal-kapal besar berlayar mengalirinya keluar masuk perairan laut di Selat Melaka.

Menurut Abdullah Zakaria (1996), Johor menguasai Selat Melaka dan menjadi pusat utama perdagangan dunia mulai tahun 1641 yakni pada masa pemerintahan Sultan Abdul Jalil Syah III (1623-1677). Johor meneruskan keagungan kesultanan Melaka yang berpusat di Melaka sebelum ini. Kawasan dan jajahannya termasuklah Selangor, Negeri Sembilan, Pahang dan Terengganu. Selain itu negeri yang sebelum ini di bawah naungan Melaka seperti Siak, Rokan, Aru dan Indragiri memberi taat setia kepada Johor. ${ }^{6}$ Manakala Andaya (1975) pula mencatatkan bahawa Johor muncul pada tahun 1641 sebagai sebuah kuasa yang walaupun wilayah kekuasaannya semakin berkurang dan kewibawaannya merosot, namun Johor masih tetap memikul matlamat ekonomi dan politik serta kepentingan kuasa sebelumnya iaitu kerajaan Melayu Melaka. Wilayah kekuasaan Kerajaan Johor berkurang kerana beberapa daerah yang penting masing-masing telah mendapatkan kemerdekaannya sejak zaman kegemilangan kerajaan Melaka pada penghujung kurun kelima belas. $^{7}$

Keistimewaan dan kegemilangan negeri Johor menyebabkan ianya sentiasa mendapat perhatian dan menggamit ramai pengkaji sama ada dari dalam atau luar negeri. Kedudukan Johor yang begitu strategik dan pembangunan ekonominya yang sangat mengkagumkan telah merakamkan pelbagai rentak alun sejarahnya yang tersendiri. Hampir pada setiap zaman, Johor sentiasa mendapat tumpuan dan rebutan daripada kuasa-kuasa asing sama ada dari Barat atau Timur. Johor juga menjadi pusat tarikan terhadap

${ }^{6}$ Abdulah Zakaria bin Ghazali. 1996. UMNO Johor: 50 tabun memartabatkan bangsa Melayu. Johor Bahru : Yayasan Warisan Johor dan Berita Publishing Sdn. Bhd, hlm. 3.

7 Andaya, 1975, The kingdom of Johor 1641-1728, Kuala Lumpur : Oxford University Press, hlm. 37 menyatakan bahawa pada tahun 1641, Kerajaan Johor hanya terdiri daripada Sungai Kelang, Sungai Penagie (Kuala Linggi), Sungai Siak, Sungai Kampar, Bengkalis, Ungaran, Pulau-pulau Karimun, Bulang, Bintan, Lingga, dan pulau-pulau disekelilingnya, pulau Singapura, RioFormosa, Sungai Batu Pahat, dan Muar. 


\section{NUSANTARA; Journal for Southeast Asian Islamic Studies}

Vol. 16, No. 1, Juni 2020

masyarakat luar khususnya dari rantau Nusantara ini. Dalam sejarahnya, Johor telah memperlihatkan kekuatan politik, pemerintahan, budaya, intelek, dan persuratan yang dapat dibanggakan. Misalnya kerajaan Johor Lama sejak tahun 1518 telah dilanggar oleh Portugis tidak kurang daripada sepuluh kali dan oleh Aceh tidak kurang daripada enam kali. ${ }^{8}$ Menurut Andaya (1975) kekerapan pelanggaran ini memperlihatkan kemampuan Johor untuk menyusun semula pertahanannya dalam masa yang agak singkat dan sekali lagi menjadi ancaman kepada Portugis dan Aceh. ${ }^{9}$

Pengasasan Kesultanan Johor pada tahun 1528 adalah disebabkan oleh kejatuhan Melaka di tangan Portugis pada tahun 1511. Sultan Melaka yang terakhir yaitu Sultan Mahmud Syah I bersama keluarga dan pembesarnya berhasil mengundurkan diri. Ketika berada dalam pengunduran diri ini, Sultan Mahmud Syah I melancarkan beberapa kali serangan untuk mengambil kembali Melaka daripada tangan Portugis, namun usaha tersebut gagal. Kekuatan Portugis ternyata tidak dapat ditandingi oleh kekuatan Kerajaan Melayu-Johor. Tambahan pula taktik yang digunakan oleh Portugis yaitu menyerang tempat-tempat yang membekalkan tenaga tentera kepada Sultan Mahmud I dan kemudian barulah menyerang Bintan yang menyebabkan sultan tidak mendapat bantuan. Setelah Bintan dimusnahkan barulah Sultan Mahmud I melarikan diri ke Kampar dan pada tahun 1528 Sultan Mahmud mangkat di Kampar dan digantikan oleh putera baginda yang bernama Raja Ali dengan gelar Sultan Alauddin Riayat Syah II yaitu anak baginda dengan Tun Fatimah.

Tahun 1641 amatlah penting dalam perkembangan sejarah Johor. Bermula tahun 1641, kedua-dua kuasa Portugis dan Aceh tidak lagi mengganggui Kerajaan Johor kerana kekalahan Portugis atas pasukan Belanda dengan bantuan pasukan Johor yang dipimpin oleh Seri Raja Diraja anak Laksamana Johor. Sebulan selepas peristiwa itu, Sultan Iskandar Thani Aceh pula mangkat. Ekoran kemangkatan Iskandar Thani, Aceh menjadi lemah kerana pada masa

8 Kassim Thukiman, Yahaya Abu Bakar, Mahmud Embong, (ed), 2001, Menelusuri sejarah tempatan Johor. Johor Bahru: Yayasan Warisan Johor, hlm. xiii -xvi.

9 Andaya, 1975, op.cit,. hlm. 31. selanjutnya Aceh dipimpin oleh sultanahsultanah. Di samping itu, faktor internal Johor sendiri seperti sokongan Orang Laut, daulat keturunan Melaka, peranan pembesar dan majlis Orang Kaya Johor memberi pengaruh ke atas perkembangan kekuasaan Johor. Johor muncul sebagai sebuah kuasa di Kepulauan Melayu dan mengalami kemantapan kerajaannya. Pada masa itu, sempadan wilayah Johor ${ }^{10}$ mulai jelas merangkumi sungai Klang, sungai Penangi (Kuala Linggi), sungai Siak, sungai Kampar, Bengkalis, Unggaran, Pulau-pulau Karimun, Bulang, Lingga, Bentan, dan pulau-pulau sekelilingnya, pulau Singapura, Riau, sungai Batu Pahat dan Muar. Manakala sebelum masa ini kerajaan Melaka mengandungi negeri Pahang, Trengganu, Kelantan, pulau-pulau di selat Singapura, Kepulauan Riau-Lingga, Kampar, Siak, Indragiri, dan juga Rokan.

Kecakapan Johor mengendalikan barang dagangan dan kemampuannya untuk membekalkan semua kapal-kapal dengan cepat dan murah adalah faktor utama yang disebut dan dikagumi oleh Belanda sebagai suatu daya tarik yang penting kepada pedagang asing. Pertimbangan-pertimbangan seperti ini penting disebabkan faktor masa adalah sangat berharga kepada para pedagang yang sangat bergantung kepada perubahan angin monsun untuk membolehkan mereka bertolak dari pelabuhan negeri masing-masing belayar ke pelabuhanpelabuhan asing dan kemudian pulang semula ke negeri masing-masing. ${ }^{11}$ Utusan Belanda yang sampai ke kota-kota di sepanjang sungai Johor dan Riau merasa kagum dengan kegiatan perdagangan yang mereka temui. Keadaan demikian dapat dilihat kepda surat yang ditulis oleh Gabenor Thomas Slicher Melaka ke Betawi pada bulan Mei pada tahun 1687 yang mengandungi antaranya "... bilangan kapal yang berlayar ke Riau yang pada masa itu ibu negeri Johor begitu besar sehingga sungai itu sukar untuk dilalui karena terlalu banyaknya kapal-kapal dagang . . . , pedagang-pedagang tertarik ke Riau disebabkan oleh pengaturan yang cepat dan mudah. Di sini para pedagang timah dibayar

10 C. H. Alexandrowicz, 1967, Introduction to the bistory of the law of nations in the Easth Indies. London : Oxford University Press, hlm. 67-8.

11 Andaya, 1975, op.cit. hlm. 38. 
setengah dengan uang dan setengah lagi dengan kain, manakala di Melaka mereka dibayar dengan apa saja jenis kain yang ada dan bukannya jenis kain dengan corak yang terbaharu seperti di Riau." 12

Dalam masa kejayaan itu, kekuatan Johor terjejas karena Johor dikalahkan oleh Jambi pada tahun 1673. Peperangan ini bermula daripada peristiwa pemutusan tunangan Yamtuan Muda Raja Bajau (bakal Sultan Johor yang memerintah di negeri Pahang) oleh Sultan Abdul Jalil yang tidak setuju Raja Bajau dikawinkan dengan anak Raja Jambi. ${ }^{13}$ Akibat dari itu, Raja Jambi sangat marah atas perbuatan Sultan Johor itu dan semenjak itu Jambi dengan Johor bermusuhan sehingga selalu berlaku peperangan. Puncaknya terjadi pada bulan Mei 1673 di mana angkatan perang Jambi telah datang secara tiba-tiba membinasakan Bengkalis daerah takluk Kerajaan Johor dan menyerang kampung-kampung di tepi Sungai Johor, kemudian menyerang Batu Sawar tempat bersemayam Sultan Abdul Jalil. Akhirnya Johor kalah juga ditangan Jambi.

Peristiwa kekalahan itu telah memaksa Sultan Abdul Jalil Syah III berundur ke Pahang. Sebelum pengunduran itu baginda memberi kuasa penuh kepada Laksamana Tun Abdul Jamil untuk membina kembali kekuatan bagi menuntut bela dan memulihkam marwah Kesultanan Johor. Dalam hal ini Laksamana Tun Abdul Jamil memilih Bintan sebagai pusat pertahanannya.

\footnotetext{
12 Surat-surat tersebut telah dikumpulkan oleh A.A. Cense, "Eenige aantekeningen over Makassar-Boeginese geschiedschrijvig", dalam BKI, CVII, 1951, hlm. 47.

13 Buyong Adil, 1971, Sejarah Johor, Kuala Lumpur : Dewan Bahasa dan Pustaka Kementerian Pelajaran Malaysia, hlm. 74 - 77 menyebutkan bahawa pada tahun 1663 Raja Bajau bertunangan dengan anak Raja Jambi, akan tetapi pada tahun 1664 pertunangan itu diputuskan oleh Sultan Abdul Jalil dengan tidak memberitahukan Raja Jambi. Sultan Abdul Jalil tidak bersetuju akan perkahwinan Raja Bajau dengan anak Raja Jambi karena Raja Bajau telah beristerikan anak Laksamana Tun Abdul Jamil. Laksamana Tun Abdul Jamil pada masa itu adalah seorang besar yang sangat berpengaruh dalam Kerajaan Johor dan ia jugalah yang memegang kekuasaan sebagai kuasa Sultan Johor. Dalam keadaan ini, berbeda sikap Raja Jambi dengan sikap Sultan Johor, meskipun Raja Jambi marah kepada sultan Johor, namun ia telah mengutus untuk memberitahu kepada sultan Johor bahwa ianya membatalkan pertunangan anaknya dengan Raja Bajau lalu di kahwinkan anaknya dengan orang lain, namun akibatnya permusuhan semakin tegang.
}

Selepas berundur ke Pahang, maka baginda Sultan Abdul Jalil Syah III pun mangkat pada tahun 1677. Sebelum itu pada tahun 1675 Raja Bajau pula mangkat di Pahang. ${ }^{14}$ Oleh itu, putera Raja Bajau yang bernama Raja Ibrahim dilantik dan ditabalkan sebagai Sultan Johor (ke-9). Sekali lagi keluarga Kesultanan Melaka-Johor meneruskan kembali pemerintahan Johor.

Laksamana Tun Abdul Jamil yang tinggal di Riau telah mempersilakan Sultan Ibrahim pindah bersemayan ke Riau. dan membuat tempat pusat pemerintahan di situ. Sultan Ibrahim berkahwin dengan anak perempuan Laksamana Tun Abdul Jamil. Untuk mengakhiri permusuhan dengan Jambi, maka Sultan Ibrahim menitahkan Laksamana Tun Abdul Jamil menyerang Jambi dan akhirnya Jambi kalah dan tunduk di bawah kekuasaan Johor yang berpusat di Riau. Kemenangan ini memulihkan semula marwah Johor. Oleh karena Laksamana Tun Abdul Jamil telah berjaya mengalahkan Jambi, maka Sultan Ibrahim menggelarnya dengan gelar Paduka Raja. Gelar ini adalah gelar tertinggi disandang oleh oleh pembesar Johor dan lazimnya disandang oleh Bendahara. Semenjak memperolehi gelar tersebut, kedudukannya menjadi lebih kuat ditambah lagi permaisuri Sultan Ibrahim adalah anaknya.

Apabila Sultan Ibrahim mangkat pada tahun $1685,{ }^{15}$ maka tahta kerajaan digantikan oleh putera baginda yang bernama Raja Mahmud yang ketika itu masih kanak-kanak berumur kira-kira

14 Ibid., hlm. 78 menyatakan bahwa Sultan Abdul Jalil mangkat pada tanggal 22 November tahun 1677 dan disebut Marhum Mangkat di Pahang dan disebut juga Marhum Besar. Manakala Raja Bajau mangkat di Pahang dalam usia lebih kurang 56 tahun dan meninggalkan seorang anak laki-laki yang bernama Ibrahim. Perkara yang sama dibincangkan pula oleh E. Netsher, De Nederlanders in Djohor en Siak 1605 - 1865, 1870, Batavia : Bruning \& Wijt, hlm. 50 . Ketika Johor dihancurkan oleh Jambi, raja beserta pengikutnya telah menginap di Pahang, suatu tempat yang menjadi wilayahnya, 36 mil sebelah utara selat Singapura. Dikarenakan raja telah lanjut usia maka baginda mangkat.

15 Kemangkatan Sultan Ibrahim disangkakan telah diracun oleh isteri baginda. Baginda bermaksud hendak pindah dari Riau dan bersemayam ke tanah besar Johor Lama. Kepindahan baginda tidak disukai oleh Paduka Raja Tun Abdul Jamil kerana di negeri Johor Lama pengaruh keluarga Bendahara Johor lebih kuat. Oleh sebab itu, kemangkatan baginda itu boleh jadi diracun oleh isteri baginda, anak daripada Paduka Raja Tun Abdul Jamil untuk kepentingan ayahandanya. 


\section{NUSANTARA; Journal for Southeast Asian Islamic Studies}

Vol. 16, No. 1, Juni 2020

sepuluh tahun. Raja Mahmud adalah anak lakilaki baginda dengan isterinya yaitu anak kepada Paduka Raja Tun Abdul Jamil. Disebabkan Raja Mahmud masih kanak-kanak, maka bunda bagindalah yang memangku kerajaan. Akan tetapi sebenarnya orang yang berkuasa dalam pemerintahan kesultanan Johor masa itu adalah Paduka Raja Tun Abdul Jamil. Terjadi pergaduhan di dalam kerajaan sehingga Paduka Raja berundur ke Terengganu dan tidak lama mangkat dibunuh atas arahan Bendahara Tun Habib Abdul Majid. Pada tahun 1697 Bendahara Tun Habib Abdul Majid meninggal dunia dan beliau dikenal dengan nama Bendahara Padang Saujana. Setelah beliau meninggal dunia jabatan Bendahara disandang oleh puteranya yang bernama Tun Abdul Jalil.

Pemerintahan sultan keturunan Melaka di Johor hanya dapat bertahan sehingga tahun 1699. Keturunannya yang terakhir yaitu Sultan Mahmud Syah II (1685-1699) putera Sultan Ibrahim Syah yang mangkat dibunuh oleh Megat Sri Rama salah seorang pembesar baginda. ${ }^{16}$ Oleh karena Sultan Mahmud Syah II dikatakan tidak mempunyai zuriat, maka Bendahara Seri Maharaja Tun Abdul Jalil telah dipilih dan diangkat menjadi Sultan Johor ke-11 dengan gelar Sultan Abdul Jalil Riayat Syah IV (1699-1718). Namun pada tahun 1718, Raja Kecil putera Sultan Mahmud Syah II muncul dan menuntut tahta kerajaan ayahandanya.

\section{Hubungan Siak dengan V.O.C.}

Ekspedisi awal bangsa Portugis bermula dengan ekspedisi Price Henry (1394-1460) yang menjelajahi pantai barat Afrika. Melalui ekspedisi Henry, bangsa Portugis memperoleh emas dari Afrika dan menjadikan jalur Portugal dan pantai Afrika Barat sebagai jalur perdagangan mereka. Sejak tahun 1500, bangsa-bangsa Eropa lainnya memperoleh emas dari Lisbon sebagai pusat perdagangan emas di Eropah. Pada tahun 1486, Bartholomews Diaz mencapai ujung selatan

16 Perkara ini banyak dibincangkan dalam Hikayat Siak hasil kajian Muhammad Yusoff Hashim; Sejarah Rajaraja Riau nombor Cod. Or. 7304 folio 403-409; Winstedt, 1979, hlm. 50-51; Buyong Adil , 1971, hlm. 84-85; Tuhfat a-Nafis (Virginia Matheson Hooker), hlm. 44-45.
Afrika Selatan iaitu Tanjung Harapan. Ekspedisi ini diteruskan oleh seorang pelaut Portugal bernama Vasco da Gama. Dalam ekspedisi kedua (1497-1499), Vasco da Gama sampai ke pelabuhan di India. Sekembalinya ke Lisbon dia membawa barang-barang yang sangat berharga di pasaran Eropa. Melihat banyaknya barang-barang dagangan yang dibawa ke negaranya, Raja Spanyol yang bernama Manuel (1495-1521) mengirimkan tiga belas kapal baru ke India di bawah pimpinan Pedro Alvares Cabral. Tujuannya untuk mendirikan pangkalan dagang di pelabuhanpelabuhan India. Para penguasa dan pedagang tempatan di daerah yang di datanginya dan yang tidak mau tunduk pada Portugal diserang dan ditaklukkannya. Kota-kota pelabuhan India seperti Calicut dan Goa dan pelabuhan Ormuz di Iran diserang. Pada masa gabenor Portugal yang bernama Afonso de Albuquerque ${ }^{17}$ (1509-1515) berada di India, kota-kota tersebut diserahkan kepada takhta Portugal. Demikian juga dengan pelabuhan-pelabuhan lainnya yang semula dikuasai para pedagang Islam dari Arab, India, Melayu, Maluku, dan Melaka ditaklukan dan dikuasai Portugis. Pelabuhan Melaka yang sangat padat penduduk dan strategis ditaklukan pada tahun $1511 .^{18}$

Bangsa Spanyol mengikuti bangsa Portugis melakukan penjelajahan dunia dan menjadi

17 Afonso de Albuguerque berasal daripada keluarga zaman lampau yang ternama yaitu daripada keturunan Raja Portugal dan Castile. Tanggal kelahirannya tiada pasti dan buku-buku yang ada menunjukkan tahun 1453 dan meninggal pada tanggal 20 Oktober 1516. Dia meninggal dunia ketika berusia enam puluh tiga tahun, sesudah memerintah India selama sepuluh tahun. Ianya pembina empayar Portugis. Dari Laut Merah hingga ke Melaka, sejauh tiga ribu $\mathrm{km}$, angkatan lautnya menggempur bandarbandar dan membina kubu-kubu, hampir berjaya menguasai keseluruhan perdagangan Lautan Hindi di bawah kawalannya. Masa Albuquerque dihabiskan dengan berperang di darat dan laut. Keterangan lanjut sila lihat Thomas. Foster. Earle \& JohnVilliers, 1990, Albuquerque Caesar of The East, Aria \& Philips Ltd, Teddington House, Warminster, Wiltshire BA 128 PQ.

18 Perkara ini banyak dibincangkan oleh Maruwiah Ahmat, 2006, Penjelajahan Portugis dan Sepanyol ke atas Asia Tenggara : Satu Pengamatan Semula, Shah Alam: Karisma Publications. Perkara yang sama dibincangkan oleh Atkinson, 1960, A history os Spain and Portugal, England: Penguin Books. Perkara yang sama pula dibincangkan oleh Pinto Da Franca 1970, Portuguese influence in Indonesia, Jakarta: Gunung Agung Ltd. 
pelopor kolonialisme. Setelah itu menyusul pula bangsa Belanda ${ }^{19}$ melakukan penjelajahan hingga sampai ke Nusantara. Kedatangan bangsa Belanda berkaitrapat dengan situasi politik di Eropah yang ditandai dengan adanya persaingan daripada negara-negara yang melakukan penjelajahan dunia. Pada pertengahan abad ke-16, Belanda sedang bersaing dengan bangsa Portugal dan Spanyol. Belanda yang berada di bawah jajahan Spanyol berusaha memperoleh kemerdekaan. Dalam rentang masa 1560-1648 merupakan tahun perjuangan bangsa Belanda memperoleh kemerdekaan dari Spanyol. Pada akhir abad ke-16 orang-orang Belanda hanya berperanan sebagai pedagang perantara rempah ratus antara pelabuhan Portugal dan Spanyol dengan pelabuhan Belanda untuk memasarkan rempah ratus di pasaran Eropah Utara. Namun pada tahun 1680-an jalur dagang mereka terganggu kerana Raja Spanyol dan Raja Portugal bersatu untuk menghancurkan jaringan dagang Belanda. Perkara inilah yang mengekalkan niat orang-orang Belanda untuk mencari sendiri rempah ratus dari Asia.

Petualang Belanda beruntung karena memperoleh informasi perjalanan ${ }^{20}$ bangsa Portugis di Asia dan Nusantara dari Jan Huygen van Linschoten seorang orang Belanda yang ikut bersama orang-orang Portugis ke Nusantara. Akhirnya dengan informasi tersebut Cornelius de Houtman dan Pieter de Keyser pada tarikh 2 April 1595 memimpin ekspedisi empat buah kapal yang berawak 249 orang dan bermeriam 64 buah bertolak dari pangkalan Tessel (Belanda

19 Bangsa Eropa yang paling lama menguasai Indonesia adalah Belanda. Salah satu bukti adanya penjajahan Belanda adalah dibentuknya V.O.C. atau kongsi dagang. Penjajahan tersebut telah menimbulkan sengsara rakyat Indonesia. Oleh karena itu, perlawanan terjadi di pelbagai daerah. Namun, karena belum adanya persatuan dan tidak secara serempak di seluruh negeri, maka Belanda menjadi lama bertahan di Indonesia.

20 Informasi perjalanan tersebut dibukukan dengan judul Itinerario, Voyage ofte Schipvaart naer Oost ofte Portugaels Indiens, (Catatan Perjalanan ke Timur atau Hindia Portugis) yang terbit pada tahun 1592 di Den Haaq. Buku tersebut merupakan sumber inspirasi yang lebih memperbesar keinginan pedagang-pedagang Belanda untuk mendapatkan sumber rempah-rempah. Mengenai kedatangan bangsa Belanda di Nusantara dibincangkan pula oleh Khoo Kay Kim, 1992, Kedatangan orang Eropah, Malaysia warisan dan perkembangan, Kuala Lumpur: Dewan Bahasa dan Pustaka Kementerian Pendidikan Malaysia.
Utara) untuk melakukan pelayaran ke Asia. Cornelius de Houtman mengepalai urusan pentadbiran perdagangan manakala Pieter de Keyser mengepalai urusan navigasi atau pelayaran. Tiga buah kapal sampai ke pelabuhan Banten ${ }^{21}$ pada tahun 1596, maka bermula konflik antara penduduk Banten dengan Belanda.

Jika diamati dengan seksama dapat dikatakan bahwa kedudukan geografi negeri Belanda telah mencorakkan masa depan bangsa Belanda itu dengan memberikannya banyak peluang perdagangan. Pada perkara tersebut Wilson (1957) menggambarkan negara Belanda adalah dengan kedudukannya yang merentangi muaramuara sungai besar seperti Scheldt, Maas dan Rhein, negara itu mempunyai pelabuhan yang letaknya menghadap ke arah barat yaitu ke England dan Lautan Atlantik dan disokong pula oleh daerah-daerah pedalaman negeri Jerman yang subur. Yang lebih penting lagi ialah kedudukannya yang terletak di pertengahan jalan antara kawasan yang banyak menghasilkan jagung dan kayu balak di kawasan Baltik dengan pasaran di bahagian selatan Eropah.",22

21 Perkara ini dibincangkan oleh Susanto Zuhdi 2002, "V.O.C : Awal Penjajahan di Indonesia," dalam V.O.C. di Kepulauan Indonesia : Berdagang dan Menjajah, Jakarta: Balai Pustaka. Dalam buku tersebut dijelaskan bahwa ketika itu Banten berada dalam pemerintahan Ratu Banten yang didampingi oleh Mangkubumi dengan kedudukan sebagai wali raja. Pada masa itu, wilayah Jayakarta atau Jakarta yang termasuk daerah pengaruh Banten berada di bawah kekuasaan Tubagus Angke, menantu Maulana Hasanuddin. Orang -orang Belanda yang datang pertama kalinya di pelabuhan ini mendapat sambutan baik dari Tubagus Angke dan syabandarnya. Perkara yang sama dibincangkan pula oleh Farah Karls, 1999, World History : the Human Experience, Ohio: United States, National Geographic Society. Selain itu, dijelaskan pula bahawa armada de Houtman berhasil mencapai pelabuhan Banten pada tarikh 23 Jun 1596. Armada ini tidak lama berada di pelabuhan Banten kemudian melanjutkan pelayaran menyusuri pantai utara Jawa terus ke arah timur menuju Madura. Dikarenakan bersikap kasar dan melakukan penghinaan terhadap penduduk di pelabuhanpelabuhan yang disinggahinya, ianya kehilangan banyak prajurit. Akhirnya sisa-sisa armada De Houtman kembali ke negeri Belanda pada tahun 1597 dengan muatan rempahrempah. Perkara yang sama pula dibincangkan oleh Hayes, 1971, Eropah moden hingga 1870, terj. Kuala Lumpur: Dewan Bahasa dn Pustaka Kementerian Pelajaran Malaysia.

22 Wilson, 1957, hlm. 2. Perkara yang sama dibincangkan oleh Boxer, 1983, Jan Kompeni, Jakarta : Sinar Harapan. 


\section{NUSANTARA; Journal for Southeast Asian Islamic Studies}

Vol. 16, No. 1, Juni 2020

Oleh karena kedudukan geografinya yang sangat menguntungkan untuk menjadi sebuah negara perdagangan, maka Belanda tidak lengah mengambil kesempatan tersebut meskipun pelayaran pertama ke Asia pada tahun 1596 hanya mendapat keuntungan kecil saja. Namun bangsa Belanda tetap menguatkan niatnya dengan memandangkan prospek perdagangan rempah yang sangat diperlukan terdapat di belahan timur. Blok (1900) mengatakan bahwa menjelang tahun 1600 terdapat lima syarikat yang berlainan di Amsterdam, dua buah di Rotterdam dan dua buah di Zeeland dan sebuah di Delf juga di Hoorn dan Enkhuizen yang kesemuanya bersaing dalam perdagangan rempah di Asia. ${ }^{23}$

Syarikat-syarikat tersebut akhirnya digesa supaya memberhentikan persaingan yang tidak sehat sesama mereka dan digesa pula untuk membentuk sebuah syarikat bersama yang didirikan sebagai Syarikat Hindia Timur Bersatu dengan nama Vereenigde Oost - Indishe Compagnie ${ }^{24}$ disingkat dengan V.O.C pada tanggal 20 Maret 1602. Tujuan didirikannya perkumpulan dagang ini adalah untuk mengintensifkan perdagangan di kawasan Nusantara dan menghindari persaingan tidak sehat di antara para pedagang Belanda sendiri. Selanjutnya, syarikat itu boleh atas nama Parlimen The Nedherlands untuk membuat perjanjian dengan putera dan raja-raja, membina kota, melantik gubernur dan pegawai kehakiman dan mengambil tentara upahan. ${ }^{25}$ Ketika V.O.C didirikan di kawasan Nusantara, Kerajaan Johor dalam masa itu sedang dipimpin oleh Sultan Alauddin Riayat Syah III yaitu Sultan Johor ke-6.

Menurut Boxer (1964), Van Dieman ${ }^{26}$ mengirim sepucuk surat kepada Heeren XVII

23 Blok, 1900, hlm. 289.

24 Pembentukan syarikat ini atas arahan seorang pembesar di Belanda yang bernama Johan van Oldebarnevelt.

${ }^{25}$ J. A. van der Chijs, 1859, Geschiedenis der stichting van de Vereenigde Oost-Indische Compagnie, Leyden, hlm. 11011. Perkara kedatangan V.O.C dibincangkan oleh Susanto Zuhdi, 2002, "V.O.C : Awal Penjajahan di Indonesia, dalam V.O.C. di Kepulauan Indonesia : Berdagang dan Menjajah, Jakarta : Balai Pustaka.

26 Anthonio van Dieman adalah seorang Belanda datang ke Batavia (Indonesia) pada tahun 1617. Pada awalnya ke Batavia untuk mencari kerja di syarikat kerajaan Belanda. Ia seorang yang gigih lagi semangat dalam bekerja. Pelbagai upaya dilakukan sehingga ianya berjaya mengembangkan VOC di Nusantara. Sepanjang hidupnya untuk memberitahu bahwa ia menggesa para pengarah supaya lebih tegas mengenai dasar VOC di Asia. Ia mengatakan juga bahwa berdasarkan pengalaman sehari-hari, dia berpendapat perdagangan di Asia tidak dapat dikekalkan tanpa penaklukan wilayah. ${ }^{27}$ Oleh karena itu dapat dikatakan VOC merupakan hasil ciptaan negara dagang yang baru muncul kemudian menjadi landasan dalam mengembangkan keinginan bangsa pedagang itu di timur.

Dalam catatan Netscher ${ }^{28}$ tertulis bahwa pada tahun 1606 dibuat perjanjian pertama antara Belanda dengan Sultan Johor yaitu Sultan Alauddin Riayat Syah III. ${ }^{29}$ Manakala perjanjian kedua antara Belanda dengan Sultan dibuat pada tanggal 23 September 1606. Perjanjian kedua tersebut dibuat karena perjanjian pertama tidak dapat segera dilaksanakan. Hubungan Johor dengan Belanda yang pada awalnya baik karena sependapat bahwa Portugis adalah musuh "bebuyutan" bagi keduanya, namun menjadi berubah disebabkan Sultan mengadakan perdamaian pula dengan Portugis. Perkara tersebut sangat merugikan Belanda. Oleh sebab itu, laksamana Pieter Willemsz Verhoef ${ }^{30}$

di Nusantara, ianya selalu pergi dan balik bahkan ianya menjadi orang hebat mengemudi kapal di Nusantara.

27 Boxer, "The Acehnese Attack on Malacca in 1629, as described in Contemporary Portuguese Sources", dalam Bastian dan Roolvink (ed.), 1984, Malayan and Indonesian Studies, Oxford: University Press, hlm. 95.

28 Netscher De Nederlanders in Djohor en Siak 1602 tot 1865 Historische Beschrijving. Buku tersebut dicetak pada tahun 1870 di Batavia. Dalam buku itu ditulis mengenai perjanjian pertama Sultan Johor dengan Belanda yang terdiri atas 13 pasal dan dibuat di atas kapal yang bernama Oranje yang bersandar di dermaga Melaka pada tarikh 17 Mei. Perkara yang sam juga tercata dalam tulisan E. Netsher yang lain Beschrijuing $V$ an Een Gedeelte DerResidentie Riouw, Batavia : Lange, Diterbitkan oleh TBG no. 2 tahun 1854.

29 Sultan Abdul Jalil Riayat Syah III memerintah bermula tahun 1597 sampai tahun 1615. Pada tahun 1605 kapal Belanda banyak bertambat di Johor. Pada perkara tersebut tidak ada serangan dari Portugis. Dan selanjutnya baginda pernah menolak permintaan gabenor Melaka untuk mengeluarkan Belanda dari Johor.

30 Verhoef berangkat dari Belanda tarikh 22 Desember 1607 dan pada tarikh 24 November 1608 sampai di Melaka. Pada hari itu juga dikirim surat kepada Abraham van den Broeck seorang pedagang Belanda yang ditinggalkan Matelief di Johor. Broeck datang menjumpai Verhoef di kapal pada tarikh 12 December 1608. Kemudian pada tarikh 05 January 1609 Verhoef dan armadanya 
diperintahkan berangkat dari Belanda dengan satu armada yang terdiri dari tiga belas kapal untuk melaksanakan perjanjian yang telah dibuat oleh Matelief dengan Sultan Johor untuk menyerang Melaka dari laut manakala sultan akan menyerang dari darat.

Keadaan di Johor semakin tidak tenang setelah diadakan perdamaian antara sultan Alauddin dengan Portugis yang dilaksanakan pada tanggal 16 Oktober 1610. ${ }^{31}$ Perdamaian tersebut telah menimbulkan permusuhan Johor dengan Sultan Aceh yang pada masa itu sedang berperang dengan Portugis. Ekoran perkara itu Johor direbut Aceh sehingga sultan bersama keluarganya dan beberapa orang Belanda ditawan dan dibawa ke Aceh. Namun tidak lama kemudian Sultan Aceh mengizinkan Sultan Johor dan keluarganya kembali ke Johor dengan perjanjian bahwa Johor akan membantu Aceh memerangi Portugis. Akan tetapi perjanjian tersebut tidak ditepati Johor, maka pada tahun 1615 Aceh kembali menyerang Johor.

Hingga kepada masa pemerintahan Sultan Abdul Jalil Syah III, Sultan Johor ke-8, banyak terjadi peristiwa di Johor yang memberi kesan kepada Siak sebagai wilayah kekuasaan Johor. Hubungan antara Johor dengan Siak menjadi lesu kerana mulai tahun 1662 Siak tidak lagi mempunyai raja sendiri sebagai perwakilan sultan Johor melainkan diletakkan seorang syahbandar yang bertugas untuk memungut cukai. Bermula dari itu, keadaan negeri Siak tidak lagi sama dengan sebelumnya dan apabila Sultan Ibrahim wafat lalu digantikan oleh puteranya yang masih kecil, pemerintahan dijalankan oleh Bendahara Paduka Raja. Pada perkara tersebut, Hall (1964) mengatakan bahawa Gabenor Melaka segera mengirim utusan untuk minta monopoli timah yang baru diperoleh di Siak. ${ }^{32}$ Pada masa itu,

bertambat di muara sungai Johor. Untuk lebih jelasnya sila merujuk kepada tulisan yang bertajuk Begin en Voortgang der Vereeningde Nederlandsch Geoctrooijeerde O. I Compagnie, yang diterbitkan tahun 1646. Pada bahagian kedua dari tulisan tersebut menceritakan Perjalanan Laksemana Pieter Williemsz Verhoef, hlm. 38.

31 Perdamaian tersebut terjadi dikeranakan adanya desakan dari saudara tiri Sultan yang berkedudukan sebagai raja di Siak di mana puterinya kahwin dengan putera tertua Sultan Alauddin pada tarikh 18 January 1610. Keterangan lanjut lihat Netscher, 1870, hlm. 42.

32 D.G.E. Hall, 1964, The history of South Asia. Kuala Lumpur : Dewan Bahasa dan Pustaka Malaysia. The history of
Bendahara Paduka Raja yang bertindak atas nama sultan membuat perjanjian pada 6 April 1685 dengan Syahbandar Francois van der Beeke dan Letnan Jan Roosdom yang bertindak atas nama Gabenor Melaka Nicolaas Schagen. ${ }^{33}$

Setelah perjanjian dibuat, Kompeni tetap mencari tahu apa yang dapat diusahakannya dalam perdagangan di sungai Siak. Kompeni mengadakan penyelidikan yang seksama mengenai perdagangan di sungai Siak kerana adanya laporan dari pedagang pembantu yang bernama Casper Temmer bahawa di Siak hanya 50 atau 60 pikul timah sahaja yang semula diperkirakan sebanyak 300 atau 400 pikul. ${ }^{34}$ Laporan dari pedagang pembantu menjadikan pihak Kompeni datang menyelidik keadaan di sungai Siak lalu Syahbandar Francois van der Beeke dan pedagang pembantu yang bernama Johannes Bonkket atas nama Gabenor Melaka Thomas Slicher menjumpai Datuk Sri Maharaja yang menggantikan Bendahara Paduka Raja yang telah wafat untuk merundingkan kontrak baru dikeranakan perjanjian sebelumnya tidak dapat dilaksanakan. Perjanjian baru dibuat pada tanggal 9 April $1689^{35}$

Kontrak atau perjanjian tersebut sangat menguntungkan kepada Kompeni karena berlakunya bebas cukai yang selama ini belum diperoleh Kompeni. Kerajaan Johor tidak hanya meliputi Semenanjung Melayu akan tetapi meliputi wilayah yang luas termasuk negeri Siak. Dengan terjaminnya perniagaan di sepanjang Sungai Siak bermakna Kompeni boleh menguasai seluruh kawasan di pedalaman Sumatera. Sebagai realisasinya Kompeni mendirikan loji di Petapahan yang terletak jauh ke hulu sungai Siak. Pada masa selanjutnya Kompeni menjumpai pula tambang-tambang timah baru di pantai timur Sumatera yang dikuasai oleh rakyat yang tidak tunduk kepada penguasa manapun. Untuk sampai ke lombong timah itu harus melalui sungai Siak.

South Asia. Kuala Lumpur : Dewan Bahasa dan Pustaka Malaysia, hlm. 317.

33 Perkara ini dicatat oleh Netscher, 1870, hlm. 5456.

34 Setelah adanya laporan dari Casper Temmer, maka pada tahun 1685 itu juga Gabenor Melaka mengangkat Teunis Jansz van Klaef menjadi kepala perdagangan di Sungai Siak

35 Netscher, 1870, op.cit., hlm. 58-60. 
Pada perkara tersebut Winstedt (1932) berpendapat bahawa perjanjian yang telah dibuat tidak akan berguna bagi Johor ${ }^{36}$ manakala Stapel (1939) sebaliknya menggambarkan bahawa perjanjian tersebut sangat menguntungkan dan berpendapat akan memperkuat posisi Belanda di Siak pada akhir abad XVII. ${ }^{37}$ Selanjutnya, Netscher (1870) mencatatkan bahawa penguasa pelombongan timah pada tahun 1676 sebenarnya telah pernah datang ke Kompeni di Melaka untuk menyerahkan timah dengan imbalan 40 ringgit untuk satu pikul seberat 375 pond. ${ }^{38}$ Sungai Siak sangat penting bagi Kompeni untuk melakukan perdagangan barang-barang lain kerana satu-satunya transportasi yang boleh digunakan pada masa itu hanyalah melalui sungai. Hal ini bermakna Siak dengan sungainya menjadi bahagian yang tidak boleh lepas dari Kompeni dalam melancarkan perjalanan kapal-kapal dagangnya.

Sultan Abdul Jalil Riayat Syah IV yang awalnya sebagai Bendahara ditabalkan menjadi Sultan Johor ke-11 pada tanggal 3 September 1699 menggantikan Sultan Mahmud Syah II yang telah mangkat dijulang. Pada mulanya sultan yang baru ini tidak mengacuhkan persahabatan yang telah terjalin dengan OIC (Kompeni Hindia Timur). Pada tahun 1705 sultan menerima kunjungan dari utusan Gabenor Melaka yang terdiri dari Letnan Jan Pietersz Theelen dan Simon Decker, akan tetapi sultan tidak mau mengadakan pembicaraan dan kemudian mengirim surat kepada Gabenor di Melaka yang mengatakan bahwa perjanjian yang dibuat tahun 1689 itu berlaku hanya sampai raja dewasa manakala raja sekarang sudah mangkat. Oleh karena itu perjanjian tersebut tidak sah lagi dan untuk selanjutnya Kompeni harus menunggu utusan raja. Dalam catatan Netscher (1870)

36 Winstedt, 1962, A history of Malaya. Singapure : Marican \& Sons, hlm. 3.

37 F.W. Stapel (ed), 1939, Geschiedenis van Nederlandsch-Indie. 5 vols. Amsterdam, hlm. 23.

38 Netscher, 1870, hlm. 62. Keterangan lanjut dikatakan bahawa pada awalnya penyerahan timah itu berjalan baik akan tetapi jumlahnya beransur-ansur menurun kerana berlaku pergaduhan di antara mereka dan juga adanya campur tangan Syahbandar Siak. yang diletakkan oleh penguasa Johor dengan menahan sebahagian timah yang dibawa melalui sungai Siak dan akan dibawa ke Riau (Bintan). dinyatakan bahwa Kompeni tetap berpegang dan menjalankan perjanjian 1689. Pada bulan Mei tahun 1706 Asisten Nicolass van Cuijlenburg dan Abraham Boone dengan kapal yang berjenama Elizabeth mengadakan pemeriksaan dagang ke Petapahan dan menukar kain-kain dengan timah. Pada waktu itu timah dihitung 30-32 ringgit sepikul dari 375 pond. ${ }^{39}$

Utusan Johor datang ke Melaka pada tahun 1710 dengan sikap seperti semula yaitu perjanjian 1689 tidak boleh dipakai lagi dan akan dibuat perjanjian baru antara sultan dengan Kompeni. Menanggapi sikap utusan Johor, pada tanggal 24 Oktober tahun itu juga, Pemerintah tinggi memerintahkan Gabenor William Six memberikan peringatan kepada sultan. Dari peringatan itu dapat difahami bahwa telah muncul masalah-masalah dalam perdagangan di sepanjang Sungai Siak karena ada sikap permusuhan dari suku Minangkabau yang menetap di sepanjang Sungai Siak terhadap Johor. Disebabkan hal tersebut, maka sikap sultan berubah terhadap O.I.C. Sultan selalu bergaduh dan keadaan ini menjadikan baginda banyak musuh. Oleh karena itu, untuk bertahan terhadap penyerangpenyerangnya baginda berpindah ke Riau dan kembali mencari sokongan kepada Kompeni Belanda dengan cara mengirim utusan ${ }^{40}$ sebagai pembawa surat Yang Dipertuan Raja Muda ke Batavia pada tahun 1713. Surat tersebut membicarakan kembali perjanjian dengan O.I.C. ${ }^{41}$ Menanggapi surat dari Johor tersebut, Pemerintah Tinggi Belanda mengutus anggota Dewan Hindia yang bernama Piteer Roselear dan Samuel Timmerman untuk mengadakan perundingan dengan utusan Johor. Perjanjian tersebut dilakukan pada 19 Ogos $1713 .{ }^{42}$

Dalam perkembangan V.O.C. menurut Boxer (1964) pada suatu masa Van Dieman mengirim sepucuk surat kepada Heeren XVII untuk memberitahukan bahawa ianya menggesa para pengarah supaya lebih tegas mengenai dasar V.O.C. di Asia. Kemudian ianya mengatakan juga

39 Ibid., hlm. 68.

40 Utusan itu terdiri dari Seri Nara Diraja, Seri Bija Wangsa, dan Raja Lela Putera yang sampai di Batavia pada bulan April 1713. Perkara ini banyak dibincangkan oleh Netscher, 1870, hlm. 69.

41 Netscher, 1870, hlm. 70-72.

42 Ibid., hlm. 72-74. 
bahawa berdasarkan pengalaman sehari-hari, kami berpendapat bahawa perdagangan syarikat di Asia tidak dapat dikekalkan tanpa penaklukan wilayah. ${ }^{43}$ Oleh itu dapat dikatakan V.O.C. merupakan hasil ciptaan negara dagang yang baru muncul kemudian menjadi landasan dalam mengembangkan keinginan bangsa pedagang itu di timur.

Perusahaan dagang ini diberikan hak istimewa oleh Pemerintah Belanda yang disebut dengan hak Octrooi yang berisi sebagai berikut.

1. V.O.C. memperoleh hak monopoli ${ }^{44}$ perdagangan.

2. V.O.C. memperoleh hak untuk mencetak dan mengeluarkan uang sendiri.

3. V.O.C. dianggap sebagai wakil pemerintah Belanda di Asia.

4. V.O.C. berhak mengadakan perjanjian.

5. V.O.C. berhak memaklumkan perang dengan negara lain.

6. V.O.C. berhak menjalankan kekuasaan kehakiman.

7. V.O.C. berhak mengadakan pemungutan pajak.

8. V.O.C. berhak memiliki angkatan perang sendiri.

9. V.O.C. berhak mengadakan pemerintahan sendiri. ${ }^{45}$

Dengan hak-hak istimewa tersebut, V.O.C memiliki kekuasan dan kewenangan yang sama seperti yang dimiliki sebuah negara. Kerana

43 Boxer, "The Acehnese Attack on Malacca in 1629, as described in Contemporary Portuguese Sources", dalam Bastian dan Roolvink (ed.), 1984, Malayan and Indonesian Studies, Oxford : University Press, hlm. 95.

44 Akibat hak monopoli yang dimilikinya, V.O.C dapat memaksakan kehendaknya pada perusahaanperusahaan perdagangan Nusantara. Tindakan ini tentu saja menimbulkan permusuhan bagi para pedagang Nusantara kerana system monopoli bertentangan dengan system tradisional yang berlaku saat itu.

45 Perkara ini dicatat dalam tulisan Taufik Abdullah, 1994, "History, Political Images and the Dutch in the Indonesian Archipelago," dalam Studia Islamica I, no. 3 (1994) : 1-24. Perkara yang sama juga dibincangkan oleh Karel Steenbrink, 1963, Dutch Colonialsm and Indonesian Islam : Contacts and Conflict, 1596-1950, translated Jan Steenbrink and Henry Janter. Amsterdam Atlanta: GA. itu, dalam menjalankan kegiatan-kegiatannya V.O.C. merupakan "negara dalam negara Belanda". Kemudian untuk mempertahankan monopoli perdagangannya, kekuatan militer dipertingkatkan. Untuk itu diperlukan bentengbenteng pertahanan yang didirikan di Ambon, Melaka ${ }^{46}$ dan di Jayakarta. ${ }^{47}$.

Hall (1964) menjelaskan bahwa pada awal abad XVIII merupakan puncak kejayaan kekuasaan V.O.C. di Nusantara, namun keadaan keuangannya yang menurun akibat perang-perang yang lama dan mahal biayanya. Begitu pula perdagangan yang merugikan disebabkan masyarakat tidak mampu membeli dengan harga tinggi yang ditetapkan Belanda di samping berlakunya perdagangan sembunyi oleh penyeludup-penyeludup Portugis dan Inggeris yang memberikan harga yang lebih baik untuk produksinya daripada kepunyaan Belanda. ${ }^{48}$

Meskipun V.O.C. telah berhasil menaklukkan berbagai kerajaan di Nusantara namun organisasi ini tidak bisa beroperasi terus. V.O.C. mengalami kemunduran yang disebabkan oleh beberapa hal yaitu :

1. Merajalelanya korupsi di kalangan para pegawai V.O.C.

2. Wujudnya persaingan yang kuat di antara kongsi-kongsi perdagangan lain.

3. Terlalu banyak biaya untuk menumpas berbagai pemberontakan rakyat.

4. Meningkatnya keperluan untuk menggaji pegawai V.O.C.

Bagaimanapun hebatnya, ternyata V.O.C. pada akhirnya harus mengalami kehancuran dan kemudian dibubarkan pada tahun 1799. Mengikut pandangan Boxer (1983) kehancuran V.O.C. disebabkan oleh perbuatan-perbuatan korupsi yang dilakukan oleh para pedagang, para pelaut, dan perajurit-perajurit yang beroperasi di Indonesia. Mereka membawa rempah-rempah milik persendirian dengan menggnakan kapal

46 Benteng di Melaka didirikan V.O.C. setelah Melaka direbut dari Portugis.

47 Kota ini menjadi pelabuhan penting alternative dari Maluku dan Melaka serta menjadi pusat operasional V.O.C atas seluruh Nusantara. Setelah Pengeran Jayakarta tidak berhasil mengusir penguasa V.O.C dan pada tahun 1619 nama bandar ini diubah menjadi Batavia.

48 D.G. E. Hall, 1964, hlm 293-294. 


\section{NUSANTARA; Journal for Southeast Asian Islamic Studies \\ Vol. 16, No. 1, Juni 2020}

V.O.C. untuk dijual di Eropah bahkan sebelum tiba di tempat tujuan dijual di tengah laut. ${ }^{49}$ Manakala Ricklefs (1998) mengatakan bahwa meskipun V.O.C. merupakan organisasi milik Belanda, tetapi sebagian besar anggotanya bukanlah orang Belanda. Para petualang, gelandangan, penjahat, dan orang-orang yang bernasib jelek dari seluruh Eropah lah yang mengucapkan sumpah setia pada V.O.C. Ketidakjujuran, nepotisme, dan alkoholisme tersebar luas di kalangan anggota V.O.C. Perkara inilah yang menyebabkan V.O.C. mundur. ${ }^{50}$

\section{KESIMPULAN}

\begin{abstract}
Negeri Siak sebelum didirikan sebagai sebuah kerajaan menjadi sebagian wilayah naungan Kesultanan Johor. Namun sebelum itu pada abad ke-15, Siak adalah sebuah negeri yang berada di bawah kekuasaan Raja Gasib yang bermukim di tepi Sungai Gasib yaitu anak sungai yang mengalir dan bergabung dengan Sungai Siak. Selepas Kerajaan Gasib dikalahkan oleh Aceh, maka Kerajaan Gasib meredam bahkan tidak pernah diketahui lagi sejarahnya
\end{abstract}

Siak dan Johor memiliki hubungan yang amat rapat karena sebelum wujud Kerajaan Siak, maka di Siak dilantik seorang raja yang bertugas sebagai wakil pemerintahan Kerajaan Johor. Dikarenakan penghasilan negeri Siak sudah mulai berkurang dan tidak menguntungkan bagi Kerajaan Johor, maka pihak Kerajaan Johor hanya menempatkan syahbandar di Siak untuk memungut hasil dan cukai bagi kapal-kapal yang berlayar di Sungai Siak. Siak merupakan pintu gerbang Johor dari arah darat Sumatera, manakala Sungai Siak pula merupakan urat nadi pengangkutan masa itu karena Sungai Siak termasuk sungai yang memiliki kedalaman sehingga memudahkan kapal-kapal besar berlayar menuju Selat Melaka.

Hubungan di antara Siak dan VOC sama saja dengan hubungan Johor dengan VOC karena pada masa itu kawasan Siak pula merupakan kawasan Johor. Hal ini bermakna apa yang

49 C.R. Boxer, 1983, Jan Kompeni, Jakarta : Sinar Harapan, hlm. 60.

50 M.C. Ricklefs, 1998, Sejarah Indonesia modern. Yogyakarta : Gajah Mada University Press, hlm. 23. berlaku ke atas Johor, maka berlaku pula di Siak. Akan tetapi, bagi Belanda, Sungai Siak yang bermula dari Selat Malaka merupakan jalur lalu lintas penting bahkan Belanda amat mementingkan Sungai Siak tersebut untuk melancarkan perjalanannya ke daerah-daerah yang diyakini memiliki hasil bumi yang amat banyak. 


\section{DAFTAR PUSTAKA}

Ahmad hariadi. Mubahalah, perang do'a melawan khalifah Qadian. Penerbit; Media dakwa. 1989.

Ahmad Jaiz, H. Hartono. Aliran dan Paham Sesat di Indonesi. Penerbit ; pustaka Al-Qausar. 2008

Ahmad Nurdin. Membendung Abmadiyah ke indonesia. Penerbit ; Sinar Islam. 1975

Ahmad Hariadi. Perang do'a melawan khalifah Qadian. Penerbit; Media Dakwah. 1989.

Alo Liliweri. Prasangka dan Konflik: Komunikasi Lintas Budaya Masyarakat Multikultur. Yogyakarta: LkiS, 2005.

Azra, Azyumardi. Pendidikan Islam: Tradisi dan Modernisasi Menuju Milenium Baru, Jakarta: Logos, 1999.

Baidhawy, Zakiyuddin \& Mutohharun Jinan (eds.), 2003. Agama dan Pluralitas Budaya Lokal, Surakarta : PSB-PS UMS.

Bogdan, R. \& S.J. Tylor, Kualitatif Dasar-Dasar Penelitian (terjemahan), Surabaya : Usaha Nasional, 1993.

Pror.Dr. Ehsan Zaheer. Qadianiat An Analytical Survey. Penerbit; Indra Tarjuman Al-

Sunnah, Lahore.

Funk and Wagnalls, Standars Desk Dictionary, Cambridge: Harper and Row, 1984.

Garna, Judistira K., Ilmu-Imu Sosial Dasar - Konsep - Posisi, Bandung : Universitas Padjadjaran, 1996.

George J. Aditjondro, Kerusuban Poso dan Morowali, Akear Permasalaban dan Jalan Keluarnya, Makalah, ProPatria, Edisi Januari 2004.

Hamid Awaludin, Perdamaian ala JK: Poso Tenang, Ambon Damai (Jakarta: Grasindo, 2010

Junus, Mahmud, Sejarah Pendidikan Islam di Indonesia, Jakarta: Mutiara, 1979.

Kami orang Islam. Penerbit; Jema'at Ahmadiyah. 1983.
Kongar, Emre. Imparatorluktan Gunumuze Turkiye'nin Toplumsal Yapisi (Struktur Masyarakat Turki dari Masa Imperium bingga Masa Kontemporer). Istanbul:Remzi Kitabevi, 1997.

Koentjaraningrat, Manusia dan Kebudayaan di Indonesia, Jakarta, Jambatan, 1971

Lerner, Daniel. Memudarnya Masyarakat Tradisional (Terj.). Yogyakarta: Gadjah Mada University Press, 1978.

Langgulung, Hasan, Aras-Aras Pendidikan Islam, Jakarta: Al-Husna, 1989.

Metoda Penelitian Pendekatan Kualitatif, Bandung : Primaco Akademika, 1999.

, Beberapa Pemikiran tentang Pendidikan Islam, Bandung: Al-Maarif, 1980.

-------. Kreatifitas dalam Pendidikan Islam, Jakarta: Pustaka al-Husna, 1992.

-------, Kreatifitas dan Pendidikan Islam: Analisa Psikologi dan Falsafah, Jakarta: Pustaka alHusna, 1991.

M. Amin Djamalludin. Abmadiyah dan pembajakan Al-Qur'an. LPPI. 2000

Moleong, Lexy J., Metode Penelitian Kualitatif, Bandung : Remaja Rosdakarya, 2000.

Muhaimin, AG., Islam dalam Bingkai Budaya Lokal Potret dari Cirebon, Jakarta Logos, 2001.

Maryam, Siti (ed.). Sejarah Peradaban Islam: dari Masa Klasik hinggga Modern. Yogyakarta: LESFI, 2004.

M. Tito Karnavian, Indonesian Top Secret: Membongkar Konflike Poso (Jakarta: Gramedia, 2008

Nasution, S., Metode Penelitian Naturalistike Kualitatif, Bandung: Tarsito, 1996.

Nils Bubant, Menuju Sebuah Politik Tradisi yang Baru?: Desentralisasi, Konflik, dan Adat di Wilayah Indonesia Timur, Antropologi Indonesia, 2004

Ozbay, Ferhunde (ed.). Women, Family, and Social Change in Turkey. Bangkok: 1990.

Ozbudun, Ergun (ed.). Perspectives on Democrasy in Turkey. Ankara: Sevinç Matbaasi,1988. 
Ozey, Ramazan. Dünya Platformunda Türk Dünyasi. Konya: Oz Egitim Yayinlari, 1997

Peursen, C.A. Van, Strategi Kebudayana, Yogyakarta, Yayasan Kanisius, 1976

Redfiled, Robert, The Little Community and Peasant Society and Culture, Chicago : Chicago University Press, 1961.

Safi'i R, Batuah. Ahmadiyah apa dan mengapa. penerbitan jema'ah Ahmadiyah Indonesia,

1986.

S. Ali Yasir. Gerakan pembaharuan dalam Islam. Yayasan Perguruan Repuplik Indonesia. 1994.

Soehartono, Irawan,. Metode Penelitian Sosial, Bandung: Rosadakarya, 1995

Sumardi, Mulyana,. Sejarah Singkat Pendidikan Islam di Indonesia 1945-1975, Jakarta: Dharma bakti, 1978

Sinanoglu, Suat. Aspects of Turkey. Ankara: Demircioglu Matbaacilik, 1989.

Sirriyeh, Elizabeth. Sufis and Anti-Sufis. England: Curzon Press, 1999.

Sonyel, Salahi R. Ataturk-The Founder of Modern Turkey. Ankara: Turkish Historical Society Printing House, 1989.

Tri Ratnawati, Antara Kekerasan dan Konstetasi Politik: Membangun Demokrasi Pasca Konflik Kasus Ambon, Berita IPTEK, Tahun Ke-45, Nomor 1, 2006

Turner, Bryan S. Sosiologi Islam: Suatu Telaah Analitis atas Tesa Sosiologi Weber (terj.). Jakrata: Rajawali Pers, 1984.

------- Atatürk's Republic of Culture. New York: The Office of the Ambassador for Cultural Affairs, Republic of Turkey, 1981.

------- The Ottomans A Brief Story of World Empire. Ankara: Ministry of Foreign Affairs of the Republic of Turkey, 2000.

---------Turkey and the European Union: an Overview. Ankara: The Ministry of Foreign Affairs of the Republic of Turkey, 2001.
Usman, Husaini dan Purnomo Setiady Akbar, 1996. Metodologi Penelitian Sosial, Jakarta : Bumi Aksara 